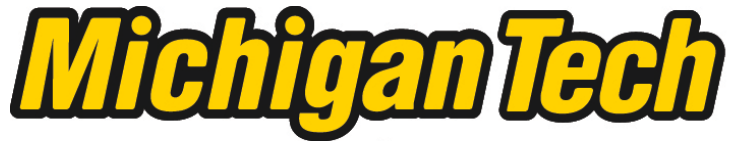 \\ Michigan Technological University Create the Future Digital Commons @ Michigan Tech
}

\section{Using contingent valuation to estimate willingness to pay for improved water source in rural Uganda}

Steven G. Wright

Michigan Technological University

Follow this and additional works at: https://digitalcommons.mtu.edu/etds

Part of the Civil and Environmental Engineering Commons

Copyright 2012 Steven G. Wright

\section{Recommended Citation}

Wright, Steven G., "Using contingent valuation to estimate willingness to pay for improved water source in rural Uganda ", Master's report, Michigan Technological University, 2012.

https://doi.org/10.37099/mtu.dc.etds/522

Follow this and additional works at: https://digitalcommons.mtu.edu/etds

3 Part of the Civil and Environmental Engineering Commons 


\title{
USING CONTINGENT VALUATION TO ESTIMATE WILLINGNESS TO PAY FOR IMPROVED WATER SOURCE IN RURAL UGANDA
}

\author{
By
}

Steven G. Wright

\begin{abstract}
A REPORT
Submitted in partial fulfillment of the requirements for the degree of MASTER OF SCIENCE

Environmental Engineering
\end{abstract}

MICHIGAN TECHNOLOGICAL UNIVERSITY

2012

(C) 2012 Steven G. Wright 


This report, "Using Contingent Valuation to Estimate Willingness to Pay for an Improved Water Source in Rural Uganda" is hereby approved in partial fulfillment of the requirements for the Degree of MASTER OF SCIENCE IN ENVIRONMENTAL ENGINEERING.

Civil and Environmental Engineering

Master's International Program

Signatures:

Report Advisor

Alex S. Mayer

Department Chair

David W. Hand

Date 


\section{Table of Contents}

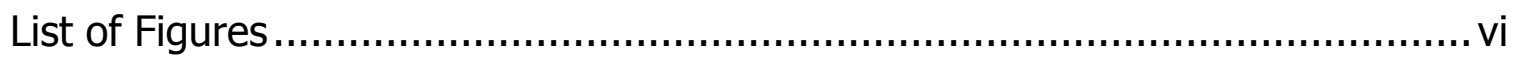

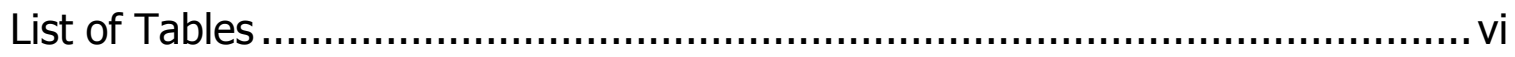

Acknowledgements .......................................................................... vii

List of Abbreviations:............................................................................ vii

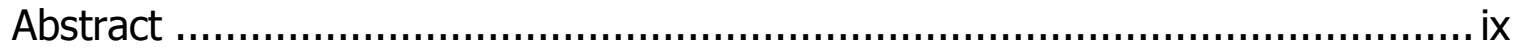

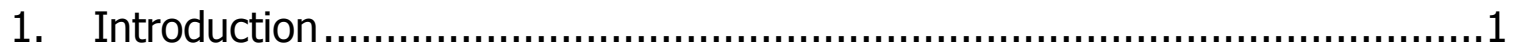

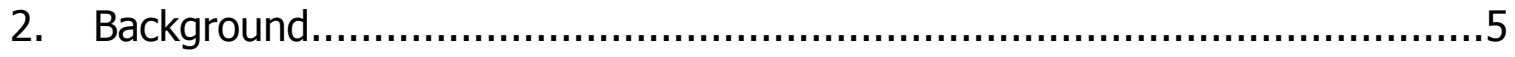

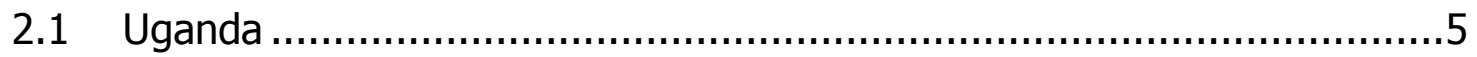

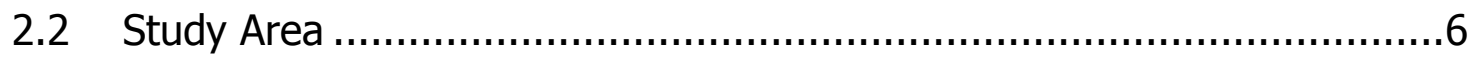

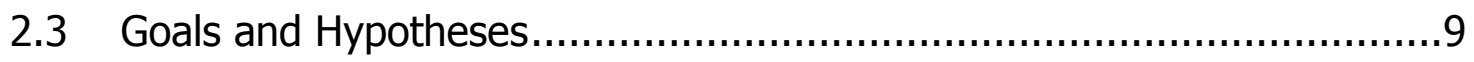

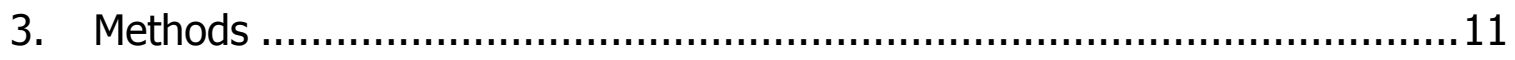

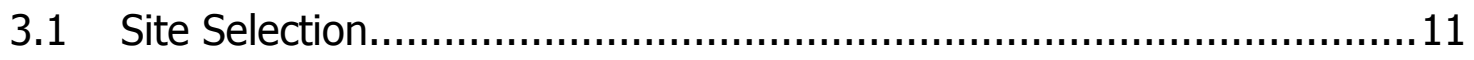

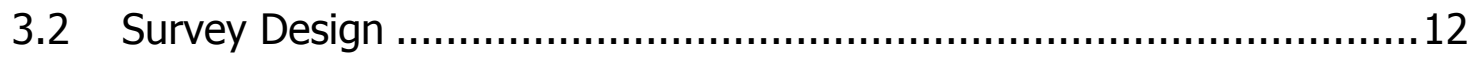

3.3 Survey Administration ........................................................... 15

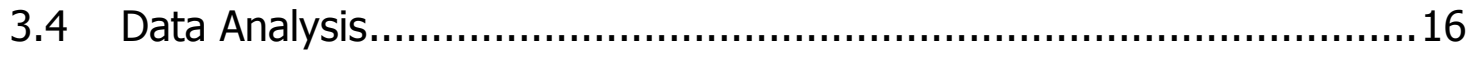

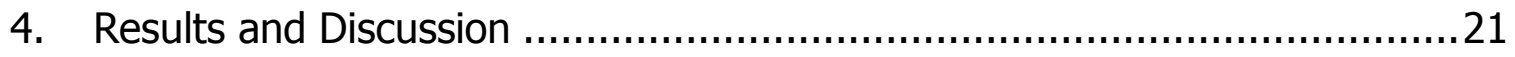

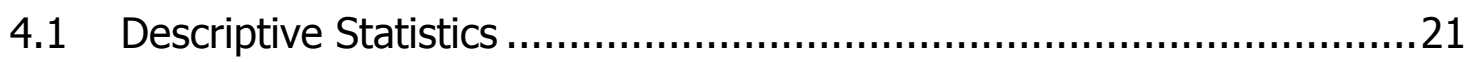

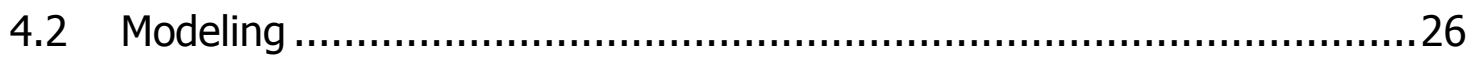

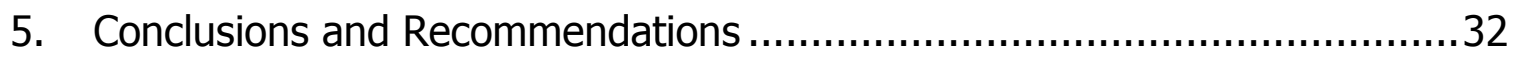

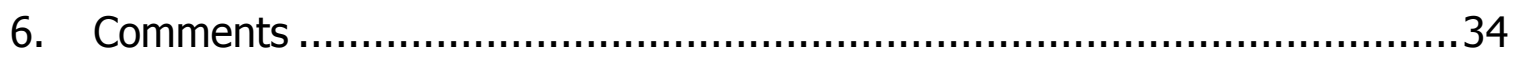

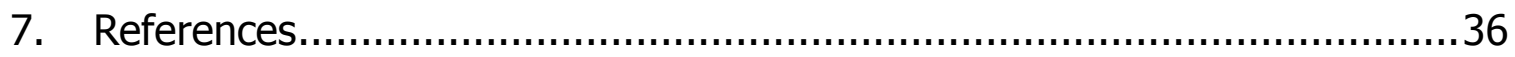

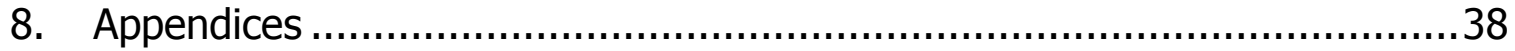

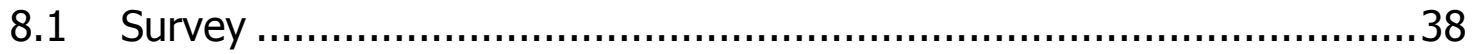

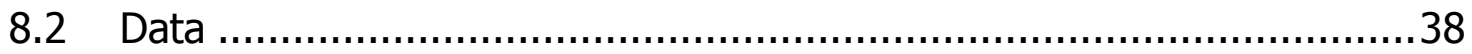

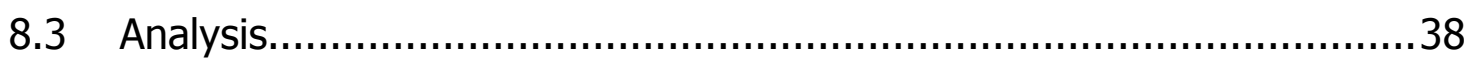




\section{List of Figures}

Figure 1: Map of Africa with Uganda Highlighted........................................6

Figure 2: Map of Uganda with Study Area Shown.......................................

Figure 3: Distribution of Household Estimated Annual Income .......................23

Figure 4: Distribution of Daily Water Use Per Capita ....................................24

\section{List of Tables}

Table 3.1 Variable Definitions, Units, and Responses...................................18

Table 4.1 Summary Demographic Information .........................................22

Table 4.2 Frequency of Diarrhea in Previous Month.....................................22

Table 4.3 Willingness to Pay for Improved Water .......................................25

Table 4.4 Goodness of Fit Statistics for Selected Models ...............................28

Table 4.5 Ordered Probit Modal A ..............................................................31 


\section{Acknowledgements}

This research and report could not have been completed without the help of many people. Their contributions were invaluable and I will be ever grateful. Much of the credit for what was done well in this report belongs to the people I acknowledge here, but any omissions, errors, or misrepresentations are mine alone. Thank you all for your help and support.

From Michigan Tech: My advisor Alex Mayer PhD, my committee, Daya Muralidharan PhD, and Brian Barkdoll PhD, and survey design advisor William Breffle PhD, PCMI Faculty Blair Orr PhD, Kurt Paterson PhD and Jim Mihelcic $\mathrm{PhD}$.

From Uganda: Peace Corps Uganda staff, Jan Droegkamp, Mercy Issali, Josephine Nampijja, David (Kimuli) and Gertrude Paradis, John Kyewalabye, KIDECAFO, the people of Kigisu and Rubona, and my good friend Patrick Kabuleeta

From my life: My roommates and friends, Ryan Biehl, Evan Anderson and Colin Casey, Michigan Tech PCMI community, and lastly my mom and dad whose support and love has allowed me to reach this goal in my life.

Lastly, I want to thank Katherine Wagner for the love, strength, knowledge, comfort, motivation, and countless other gifts she has given me to make this possible. I love you. 


\section{List of Abbreviations:}

$\mathrm{CBO}$

CVM

DALY(s)

KIDECAFO

MDG

NGO

O\&M

UGX

WTA

WTP
Community Based Organization Contingent Valuation Method Disability Adjusted Life Year Kasambya Integrated Development and Care Foundation Millennium Development Goal(s) Non-Governmental Organization Operation and Maintenance Ugandan Shillings Willingness to Accept Willingness to Pay 


\section{Abstract}

This research was conducted in August of 2011 in the villages of Kigisu and Rubona in rural Uganda while the author was serving as a community health volunteer with the U.S. Peace Corps. The study used the contingent valuation method (CVM) to estimate the populations' willingness to pay (WTP) for the operation and maintenance of an improved water source. The survey was administered to 122 households out of 400 in the community, gathering demographic information, health and water behaviors, and using an iterative bidding process to estimate WTP. Households indicated a mean WTP of 286 Ugandan Shillings (UGX) per 20 liters for a public tap and 202 UGX per 20 liters from a private tap. The data were also analyzed using an ordered probit model. It was determined that the number of children in the home, and the distance from the existing source were the primary variables influencing households' WTP. 


\section{Introduction}

Increased access to improved water sources is recognized as critical to improving health and promoting poverty reduction in the developing world. While the world is on track to meet the drinking water portion of Millennium Development Goal (MDG) 7.3, halving the population without access to improved water and sanitation, there are still vast numbers of people without access to improved water. Currently $80 \%$ of those without access to improved water live in rural areas (UNDP 2010). While improving access to water has been the focus of many development agencies and governments around the world, there is still a lack of good data on consumers' willingness to pay for these services. This limits private interest in developing water sources since there is no indication of which projects may be profitable, or sustainable.

Even when new sources are constructed, these sources are often not used nor maintained properly. Some estimates indicate more than $25 \%$ of rural water systems in the developing world are not working, with some countries new construction efforts being exceeded by the rate of failure (Mu et al. 1990). Observations made by the author of communities in Uganda support these statements. One reason for these failures is a long held belief by development planners that as long as the cost of an improved water source does not exceed $5 \%$ of income, then consumers willingly switch to using the improved source (Van Damme 1984). This assumption has been called into question by a growing body of literature on the subject of willingness to pay for improved water in developing countries (Whittington et al. 1991; Alexander McPhail 1993a; Alexander A. McPhail 1993b; Goldblatt 1999). One study in rural Zimbabwe showed that households were unwilling to pay more than $0.5 \%$ of their income for protected wells because they were seen as only a marginal improvement over existing sources (Briscoe et al. 1990). Other studies have found that rural 
communities in Thailand and India were willing to pay significantly more than $5 \%$ for a private tap (Mu et al. 1990). One study in El Salvador showed a WTP up to $30 \%$ of income for a private tap (Perez-Pineda 1999). It is clear that there is no single value that can be used for estimating WTP for improved water.

Water demand models are common and yield predictable results in almost any part of the industrialized world. This is due to the fact that improved water is a homogeneous product in these places. If a household is going to participate in the water system, they will connect and typically have multiple taps in the yard and inside the home. These water systems provide a constant, reliable supply of safe water at a consistent pressure, for the most part. Demand in these circumstances has been shown to be inelastic in relation to price. This is partly because of a lack of viable substitutions for the standard water system (Nauges and Whittington 2010). People from New York City are not going to carry their water for washing from the East River every day. There are simply no viable alternatives to the large-scale public water systems in those areas.

In most areas of the developing world, households have access to water from a variety of sources. These sources will vary greatly in their ease of use, quality, quantity, price, reliability and other factors that influence the households demand for water from that source. These variables for each water source are joined by social, cultural and even political factors to create an extremely complex decision making process when it comes to households water choices. This complexity explains why typical demand-price models simply do not work for the developing world and other methods must be used to evaluate households demand for an improved water source.

Due to the myriad factors that influence consumers' water use decisions in the developing world, individual water projects must undertake the work of understanding the specific needs and desires of the population they intend to 
serve. The factors that affect households WTP for improved water sources are too heavily influenced by specific circumstances, culture, and various social factors to be used outside of the specific scope of a study (Wedgewood and Sansom 2003). Therefore each WTP work should be considered a case-study and any conclusions should be considered to be of limited utility for policy and decision making outside the scope of the study.

WTP can be evaluated using several different methods depending on the researcher and the good or service being examined. Most studies use WTP to determine the value people place on non-market goods and services; however researchers may use revealed preference methods to estimate WTP if a market exists for the good or service. Contingent Valuation Method (CVM) is a stated preference method since the respondents are asked to state their willingness to pay contingent on the provision of some hypothetical good or service.

While CVM is used for estimating willingness to pay for a variety of non-market goods and services, it is commonly used for water and sanitation studies. The body of CVM studies related to improved water sources in rural communities in developing countries has shown inconsistency regarding significant covariates. Examination of a number of CVM studies reveals that where econometric tests are carried out, the statistical significance of predictive variables are inconsistent. Sometimes the education level of respondents proves to be significant (Singh et al. 1993; Wedgewood and Sansom 2003; Abdul and Eatzaz 2007). Another study reported that 'more educated respondents generally bid more than less educated respondents, but this effect is statistically significant in only a few of the models and its magnitude is always small' (Whittington et al. 1990), while some studies report that there is no statistically significant relationship between education and WTP (Boadu 1992; Perez-Pineda 1999). The impact of education varied from one study to the next and yet the suggestion from all reports was that their results 
were valid and provided accurate demand assessment data. Given the specific use of any WTP study, it is important for researchers to develop practices that are cost effective and produce reliable results.

The use of CVM has not been universally accepted as a reliable tool for evaluating WTP. There are critics of the CV method (Diamond and Hausman 1994) who feel the method is fundamentally flawed. However, there is a significant amount of research which indicates that a well designed and implemented CV study will produce reasonable, predictable and reliable information (Whittington et al. 1990; Arrow et al. 1993; Whittington 1998; Carson 2000; Carson et al. 2001; Gunatilake et al. 2007). The effectiveness of CVM in WTP analysis is now widely accepted particularly when it is used to value a familiar good such as a water supply (Boardman 2006).

This study uses CVM to determine household WTP, and variables that influence WTP, for an improved water source in a rural Ugandan village. This case-study will add to a small but growing body of knowledge about specific variables relating to WTP in a rural developing nation context. Section 2 of the paper provides background information on current conditions in Uganda, the study area and the motivation for this paper. Section 3 describes the methods used. The results of the study are presented in Section 4. Section 5 discusses the results, their implications and recommendations. The paper is concluded in Section 6. 


\section{Background}

\subsection{Uganda}

Uganda is a small land-locked country in East Africa highlighted in Figure 2. Uganda has a total land area of about $197,000 \mathrm{~km}^{2}$, roughly the size of Oregon, and a population estimated at 35.9million (Government 2012). Uganda is a densely populated country with one of the highest rates of population growth in the world. With a per capita GDP of $\$ 1300$ (Economist 2010), it is also one of the poorest countries in the world. This makes it no surprise that access to improved water in Uganda is still a challenge for many.

As of $2008,91 \%$ of urban households had access to improved water sources while just $64 \%$ of rural households had access. While the urban access sounds good, it is important to note that Uganda has not undergone the rapid urbanization of other countries and $87 \%$ of the population still lives in rural areas (WHO 2008).

Poor access to water is a major contributor to health and economic problems in Uganda. The under-5 mortality rate due to diarrheal disease is $18 \%$, the largest single cause of mortality for this age group. Overall, mortality from diarrheal disease is $4 \%$, higher than malaria, resulting in an additional 30,700 deaths annually. In addition to the excess deaths, the country suffers more than 1 million estimated total Disability Adjusted Life Year's (DALY's)(WHO 2008) due to diarrheal disease.

Uganda has annual renewable water resources of $66 \mathrm{~km}^{3} /$ year (Government 2012). There are 2 distinct wet seasons each year, March-May and SeptemberNovember, with most areas, including the study area, receiving more than $1 \mathrm{~m}$ of rainfall annually. 


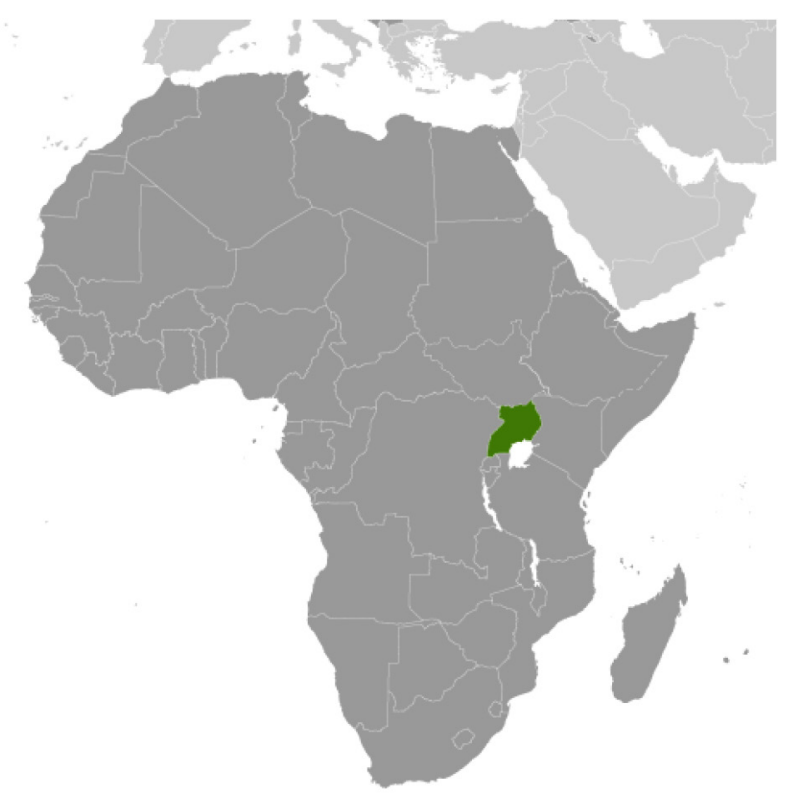

Figure 1: Map of Africa with Uganda Highlighted

Source: https://www.cia.gov/library/publications/the-world-factbook/maps/ug largelocator template.html

\subsection{Study Area}

In August of 2011 this contingent valuation study was conducted in the villages of Kigisu and Rubona, Uganda highlighted in Figure 3. These villages are located in Mubende district, on the western edge of the Buganda Kingdom. This area is remote from the cultural center for the tribe, near Kampala, and is one factor contributing to the area still being underserved by infrastructure.

Some larger villages and towns in Mubende District are served by a water system. These systems often consist of both private and public taps. A private connection requires paying a 1 time installation fee, based on the distance to the existing system infrastructure, and then a monthly bill based on metered water use. Anyone can also access water at the public tap-stands. These tap-stands sell water by the unit, typically $20 \mathrm{~L}$ as this is a standard container used in all areas of Uganda, with the price being set by the local water committee. 
These villages have been working with Kasambya Integrated Development and Care Foundation (KIDECAFO), a local Community Based Organization, to solicit help in constructing an improved village water supply. The water project is proposed to serve approximately 400 households, 2400 people, in the area. This research was conducted in close cooperation with KIDECAFO and its staff. Partnering with KIDECAFO provided access to local leaders, elected and cultural, local staff, community members to work as enumerators. KIDECAFO staff were also an invaluable source of local knowledge. The rolling topography of this region leads to most villages being located on the dryer hilltops with water sources located on valley floors. Many of these water sources are simple catchment areas for runoff, small impoundments for capturing stream flow, shallow wells, natural wetlands or springs.

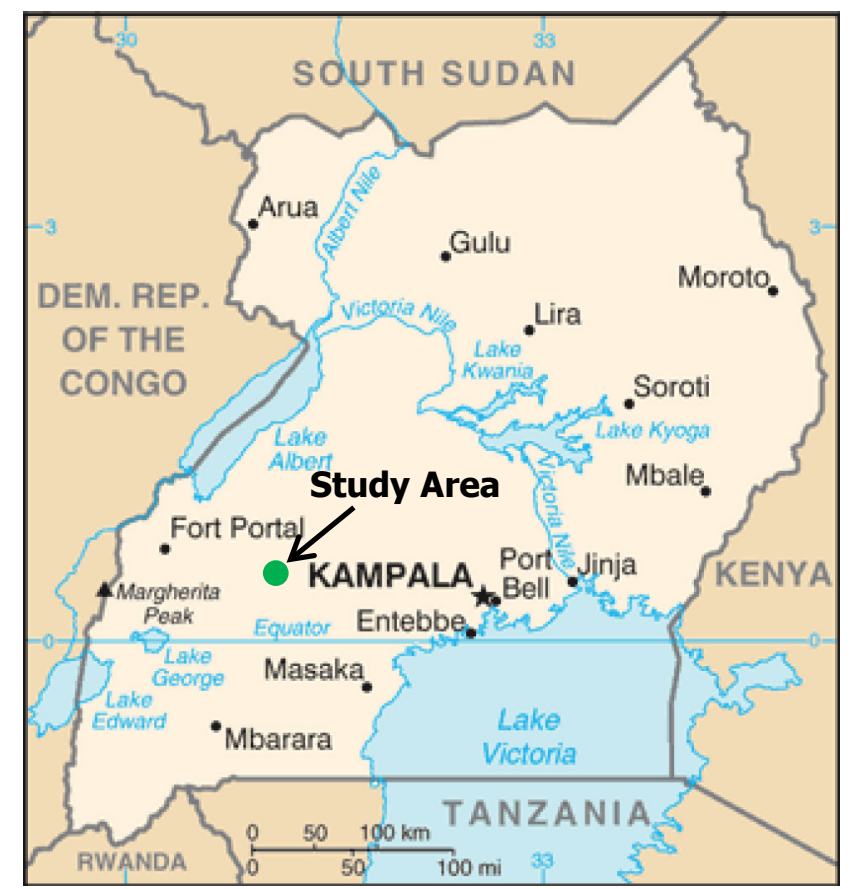

Figure 2: Map of Uganda with Study Area Shown 
The most common improved water sources are hand pumped boreholes. The boreholes are often the result of an NGO providing the water source without corresponding training on its management, operation, ownership or repair. This lack of coordination and planning has resulted in boreholes being located without a predictable pattern making access to them highly variable. The lack of, or poor, training and coordination with citizens also results in a high rate of failure for these projects. In the town of Kasambya there were 4 boreholes but only 2 were operational.

The population of the study area are primarily subsistence farmers growing maize, beans, plantains, groundnuts (peanuts), and to a lesser extent millet, cassava and coffee. Primary crops are used first as a food source, and secondly for income. Coffee, plantains and groundnuts (g-nuts) are the primary cash crops in the study area. Plantains are harvested periodically throughout the year; coffee is harvested once per year; most other crops are harvested twice per year.

Residents in the study area have access to several unimproved, open sources of fresh water. These sources were observed to be unprotected from contamination due to runoff or animal and human activities. Water is collected by submerging the container into the open water. During periods of water scarcity it is common to observe people walking into the water source to be able to collect water, adding to the contamination issue.

The closest improved source, a manual borehole, is more than $3 \mathrm{~km}$ from the village center and more than $100 \mathrm{~m}$ lower in elevation. This water source is free, but the effort required to fetch water from this source causes the majority of households to use the 'traditional' open sources combined with informal 
rainwater harvesting and storage. Some residents pay for water from the borehole to be delivered to their homes by bicycle.

Kasambya, the nearest town, has an existing piped water supply with private taps and a public tap-stand. The public tap provides water for purchase at a rate of 200 shillings per $20 \mathrm{~L}$ jerrycan, although this price does vary with the seasonal rains. During the wet season the price can drop to 100 shillings and during the most recent dry season the price increased to 300 shillings per jerrycan.

Private taps are charged a monthly connection fee of 1500 shillings and water is metered with $1 \mathrm{~m}^{3}$ costing 4000 Shillings ( $\$ 1.30$ USD), resulting in lower overall cost for most families compared to purchasing from the public tap. It may be assumed that most households would choose to have a private tap if the cost of connection were low enough, the system quality and reliability was seen as high enough, or the service was extended further from the town center.

\subsection{Goals and Hypotheses}

Development work is full of examples of projects that have been properly initiated yet failed to continue for their expected lifetimes due to some issue related to operation and maintenance. Often these failures are due to communities' unwillingness to pay even modest fees required to provide for operation and maintenance.

This research was conducted with three goals in mind. First, the results of the WTP study will be used to assist the community and KIDECAFO in their efforts to develop an improved water source for the area. This study will quantify the communities' WTP for an improved water source, thereby giving decision makers the quantitative data needed to make informed decisions about the proposed water project. 
Secondly, the research will provide useful information for KIDECAFO, and other groups operating in the area, about the communities' demographics. Like many areas in the developing world, there is very little data about the communities and its citizens. Sharing demographic information about the households in these communities will be a step towards leaders being able to make better informed decisions regarding community development.

Lastly, the research is intended to expand the limited body of knowledge regarding WTP and the factors influencing WTP for improved water in rural communities in the developing world. This research will provide information regarding rural communities' WTP for improved water within the Buganda Kingdom, Uganda, East Africa. 


\section{Methods}

\subsection{Site Selection}

The villages of Kigisu and Rubona (hereafter referred to as Kigisu), in Mubende district, West-Central Uganda are typical of the area. These are small communities, approximately 400 households combined, with a trading center where most commercial, social, and community activities take place. The trading centers are located along the main road that connects the two villages. The communities have grown in size to a point where the boundary between the communities is not apparent. Most community members are engaged in subsistence farming as their primary or secondary occupation. Kigisu is located on a ridge with valleys spreading out in several directions, approximately 100 meters above the valley floor where the traditional water sources are located.

The community is connected to other towns through a network of informal paths, locally supported roads and a dirt road that is periodically maintained by the district government. Kigisu is more than $25 \mathrm{~km}$ from the closest paved road, $30 \mathrm{~km}$ from the district capital Mubende town, and $200 \mathrm{~km}$ from Kampala, the nations' capital.

Kigisu, like many rural areas in Uganda, is not served by any infrastructure for

electricity, water, or sanitation services. The trading center has a privately owned, gas-powered generator providing electricity to light about 20 small shops and households for 3-4 hours each night through an improvised distribution system. 


\subsection{Survey Design}

The works and recommendations of previous researchers and scholars was considered for this study (Arrow et al. 1993; Whittington 1998; 2002; Gunatilake et al. 2007; Nauges and Whittington 2010). The survey was designed with four sections to elicit information on demographics, health, current water situation, and household willingness to pay for an improved water source. The survey included an informed consent statement that was read to the interview subject. Verbal consent was required due to the lower levels of education in the area. The survey instrument, including the informed consent statement, were approved through Michigan Technological University's Institutional Review Board (IRB) process, approval number M0790E. The complete survey instrument and IRB approval are included in Appendix 8.1.

In Uganda it is customary for the male head of household to be responsible for financial decisions, while the female head is responsible for almost every other aspect of the family. This means that while women are almost exclusively in charge of water collection and use within the household, the men control the money needed to make any water purchases. This raised the question of who to interview for the study. Working with KIDECAFO staff, it was determined that whoever our enumerators found at the household should be asked if they were the person responsible for making decisions about the household's water. By framing the question in this manner, our enumerators would be able to speak to either male or female heads of household without offending. The ability to gather responses from both men and women could also provide valuable data regarding gender bias towards WTP.

Once the respondents were identified, the enumerator read the informed consent statement explaining the purpose of the survey and confidentiality issues and 
then asked for consent to be interviewed after being assured they would suffer no negative consequences if they declined the interview. The respondent's names were recorded on a separate sheet along with the survey number for tracking purposes. The interview was then conducted on a separate survey form marked only with the survey number and without any personally identifiable information.

Demographic questions such as level of education, age, and number of people living in the household were asked directly. Since the majority of households in the survey area are subsistence farmers, the question of determining household income was a challenge. To overcome this difficulty, the study employed several options for eliciting income information. Respondents were directly asked for their income and that number was noted. If a respondent said they did not know their income but had noted their occupation as farmer, they were asked to provide information about their most recent harvest including which crops they grew, and what quantity they sold, in kilograms, during their most recent season. The local market price for these goods was gathered and the information was converted to an annual income for the household.

The respondents were asked if anyone in the household had experienced diarrhea, or other stomach upset, within the last month. If they responded positively they were asked the frequency for children and adults. Respondents were asked if they boil or otherwise treat their drinking water and with what frequency.

Water use was determined by asking the respondent how many containers, 20L jerrycans, they filled each day and which water sources they used. Households were asked if they purchase water, how much they pay, and how many jerrycans they purchase. 
The enumerator next described the proposed water system, including the system's major components. The proposed system was compared to a known system from a nearby town, while stressing that the proposed system would be run by a locally elected committee and not KIDECAFO or its representatives. The respondents were asked to suppose the system was already installed and to answer the WTP questions related to paying for the water they would be using from the proposed system, while reminding them that this money would be collected for the ongoing operation and maintenance needs of the system.

An iterative bidding process was determined to be appropriate based on the sample size, previous studies' recommendations (Whittington, 1993) and the common practice of negotiating in Ugandan markets and other business transactions. The Ugandan shilling (UGX) was valued at 2770:1 against the U.S. dollar (USD) at the time of the study (Yahoo 2011). The smallest denomination of currency is a 50 shilling coin, but it is uncommon in practice and typically the smallest price increment is 100 shillings. Due to these factors, bidding prices of $100,200,400,600$ and 800 were chosen. 800 Shillings was considered to be the lowest value we would expect to receive almost universal rejection.

To control for starting-point bias, surveys started at either a high-bid (800 Shillings) or low-bid (100 Shillings) and then proceeded until the highest amount the respondent was willing to pay was recorded. In the case of ascending bids, the first no response then indicated the willingness to pay for that respondent was between the most previous yes response and the value they rejected. For those that started with the high bid, the first yes indicated a willingness to pay some value between that value accepted and the previous rejection.

The study was designed in English, which is the national language of Uganda but is not widely spoken by the rural populations where education levels are lower. The completed survey was then translated into Luganda, the primary language 14 
of the study area and most widely used language in Uganda, then re-translated to English to check for consistency.

\subsection{Survey Administration}

The survey was administered with the cooperation of local leaders, KIDECAFO, and a group of local youth. The study was implemented during the month of August due to the fact that schools were on term break and farming activities would not have begun in earnest, so it would be easier to find people in their homes. Fifteen youth, a combination of students in their Senior-4 year, or higher (equivalent of freshman year in high school), university students, and new teachers were recruited as enumerators.

Enumerators, KIDECAFO staff and several local leaders participated in two days of training. These sessions focused on helping the enumerators to understand the purpose of the survey, content and proper questioning technique. The sessions combined lecture and role playing with enumerators practicing the survey on each other while being observed and provided feedback. These sessions served to further test the survey for proper design and translation. During the training several changes to the survey were implemented based on valuable feedback from the participants.

The village was divided into five sections based on major road divisions and household density. Enumerators were paired and assigned to a specific section with instructions to interview every other household in the section. One of the pair would observe while the other conducted the interview. The interviews were occasionally observed by a survey administrator for additional quality assurance. While there was no formal sampling frame available for the area, the system was effective at covering the community with more than $30 \%$ of households being sampled. 
After the first day of interviews the enumerators, and KIDECAFO staff, expressed concern about question 19, WTP for a private tap. Enumerators were challenged by many respondents due to the current lack of any water system in the area and the households distance from the village center. Enumerators and KIDECAFO staff expressed unwillingness to ask the question based on its unrealistic assumption that private taps would be available, especially to households outside of the main trading center. Based on this feedback the question about WTP for a private tap was eliminated on the second day of interviews. This resulted in $n=54$ surveys for WTP for a private tap and $n=122$ surveys for WTP for a public tap.

\subsection{Data Analysis}

Data analysis was done using IBM's SPSS statistical analysis software programs. Descriptive statistics were run against all variables to determine mean, median, standard deviation and frequencies of data. One-way ANOVA testing was used to compare the WTP results for each team of enumerators.

A correlation matrix was created for all variables to identify significant relationships of the independent variables to the dependent variable, WTP. The matrix also identified significant relationships between independent variables. These relationships were used to guide the creation of a predictive model for household WTP. Data files are included in Appendix 8.2.

The data was modeled in order to check results against other studies and verify predicted relationships among variables as a further validation of the data. For the modeling exercises, WTP is treated as an ordinal variable because it consisted of 6 discrete categorical responses. Econometric analysis of an ordinal variable and a combination of scalar and nominal independent variables requires the use of models such as the ordered probit model used here. The probit model 
essentially estimates the probability of a given level of WTP as a function of the independent variables. SPSS software uses the generalized linear equation (shown below) in conjunction with the probit link equation (also below).

The basic form of a generalized linear model is shown in the following equation.

$$
\operatorname{link}\left(\gamma_{\mathrm{ij}}\right)=\theta_{\mathrm{j}}-\left[\beta_{1} \mathrm{x}_{\mathrm{i} 1}+\beta_{2} \mathrm{x}_{\mathrm{i} 2}+\ldots+\beta_{\mathrm{p}} \mathrm{x}_{\mathrm{ij}}\right]
$$

where:

$\operatorname{link}() \quad=$ the link function

probit link function $=\mathrm{F}^{-1}(\mathrm{x})$

$\gamma_{i j}$

$\theta_{\mathrm{j}}$

$\mathrm{p}$

$x_{i 1} \ldots x_{i p}$

$\beta_{1} \ldots \beta_{\mathrm{p}}$
$=$ the cumulative probability of the $\mathrm{j}^{\text {th }}$ category for the $\mathrm{i}^{\text {th }}$ case

$=$ the threshold for the $j^{\text {th }}$ category

$=$ the number of regression coefficients

$=$ values of the predictors for the $\mathrm{i}^{\text {th }}$ case

$=$ regression coefficients

A comprehensive analysis of the variables (shown in Table 3.1) and how significant they were to the dependent variable, WTP, was undertaken. For each model the difference of the -2 log-likelihoods between the baseline model and the final model, the Cox and Snell, Nagelkerke and McFadden pseudo $\mathrm{R}^{2}$ statistics were compared along with the chi-square value from the Test of Parallel Lines. For those models that showed strong predictive ability the independent variables were then examined for their sign, coefficient and significance. The signs were critically examined and compared to the expected outcomes.

After the predictive ability of the model was verified the independent variables were evaluated for sign, magnitude of coefficient and significance. Through multiple iterations, the variables consistently showing strong significance, or linked to improved 'goodness of fit', were noted and used to generate a series of models with strong predictive power. 
Table 3.1

Questions Asked and Information Gathered in the Survey

\begin{tabular}{|c|c|c|}
\hline Variable & Question/Information & Response \\
\hline Adults & $\begin{array}{l}\text { How many adults live in the } \\
\text { household? }\end{array}$ & Scalar \\
\hline Age & Age of respondent? (years) & Scalar \\
\hline Agebin & Binned Age of respondent & Nominal Ranking \\
\hline Altsource & $\begin{array}{l}\text { What is the household's alternate } \\
\text { water source? }\end{array}$ & $0=$ Rainwater; 1=Lake; 2=Dam \\
\hline Bids & $\begin{array}{l}\text { Did the respondent have increasing or } \\
\text { decreasing bids in survey? }\end{array}$ & $0=$ Increasing $; 1=$ Decreasing \\
\hline Boil & Does household boil drinking water? & $0=$ Yes; $1=$ No \\
\hline Boilfreq & How often is drinking water boiled? & $0=$ Always $; 1=$ Sometimes \\
\hline Children & $\begin{array}{l}\text { How many children live in the } \\
\text { household? }\end{array}$ & Scalar \\
\hline Comment & $\begin{array}{l}\text { Respondent additional comments or } \\
\text { question }\end{array}$ & $\begin{array}{l}0=\text { Support Project; } 1=\text { Concerned } \\
\text { about Over-charging; } 2=\text { Request } \\
\text { Additional Services; } 3=\text { =ater Should } \\
\text { come from Mubende; } 4=\text { =oubtful of } \\
\text { Project Completion; } 5=\text { =Appreciate } \\
\text { Due to Water Scarcity; } 6=\text { =Appreciate } \\
\text { Due to Water Cleanliness; } 7=\text { Support } \\
\text { Project \& Request Monthly } \\
\text { Payments; } 8=\text { Express Urgency for } \\
\text { Project Completion; } 9=\text { People Will } \\
\text { Pay if Project is Completed } \\
0=\text { Beans; } 1=\text { Maize; } 2=\text { G-nuts; } \\
3=\text { Millet; } 4=\text { Cassava; } 5=\text { Coffee; } \\
6=\text { Plantain; } 7=\text { Beans \& Maize; } \\
8=\text { Maize \& G-nuts; } 9=\text { Maize \& Beans }\end{array}$ \\
\hline Crops & $\begin{array}{l}\text { If farming is an occupation, what crops } \\
\text { are grown? }\end{array}$ & $\begin{array}{l}\text { \& G-nuts; } 10=\text { Beans \& G-nuts; } \\
\text { 11=Beans \& Millet; } 12=\text { Maize \& } \\
\text { Plantain; } 13=\text { Beans \& Coffee; } \\
\text { 14=Not Specified; 15=Beans \& } \\
\text { Maize \& Coffee \& Cassava; } 16=\text { Cash } \\
\text { Crop \& Other Income; 17=Non-Farm } \\
\text { Income }\end{array}$ \\
\hline Distexist & $\begin{array}{l}\text { Household distance to current primary } \\
\text { water source }(\mathrm{km})\end{array}$ & Scalar \\
\hline Distexistbin & $\begin{array}{l}\text { Household distance to current primary } \\
\text { water source }(\mathrm{km})\end{array}$ & Nominal Ranking \\
\hline Distproposed & $\begin{array}{l}\text { Household distance to proposed public } \\
\operatorname{tap}(\mathrm{km})\end{array}$ & Scalar \\
\hline Distproposedbin & $\begin{array}{l}\text { Household distance to proposed public } \\
\operatorname{tap}(\mathrm{km})\end{array}$ & Nominal Ranking \\
\hline Education & $\begin{array}{l}\text { Years of school respondent has } \\
\text { completed }\end{array}$ & Scalar \\
\hline Educbin & $\begin{array}{l}\text { Years of school respondent has } \\
\text { completed }\end{array}$ & Nominal Ranking \\
\hline
\end{tabular}




\begin{tabular}{|c|c|c|}
\hline Variable & Question/Information & Response \\
\hline Hhwateruse & $\begin{array}{l}\text { How much water does the household } \\
\text { use daily? (Liter) } \\
\text { How many times have adults }\end{array}$ & Scalar \\
\hline Illadult & $\begin{array}{l}\text { experienced diarrhea in previous } \\
\text { month? }\end{array}$ & Scalar \\
\hline Illchild & $\begin{array}{l}\text { How many times have children } \\
\text { experienced diarrhea in previous } \\
\text { month? }\end{array}$ & Scalar \\
\hline Illness & $\begin{array}{l}\text { Has anyone in the household } \\
\text { experienced diarrhea in the previous } \\
\text { month? }\end{array}$ & $0=$ Yes; $1=$ No \\
\hline Illperchild & Diarrheal incidence per child & Scalar \\
\hline Income & $\begin{array}{l}\text { What is household annual income? } \\
\text { (UGX) }\end{array}$ & Scalar \\
\hline Logincome & Log of household income & \multirow{4}{*}{$\begin{array}{l}\text { Scalar } \\
0=\text { Very Difficult; } 1=\text { Fair; } 2=\text { =ery } \\
\text { Easy } \\
0=\text { Distance; } 1=\text { Dirty; } 2=\text { Scarcity; } \\
3=\text { Dirty \& Distance } 4=\text { Must } \\
\text { Purchase; 5=Dirty \& Must Purchase }\end{array}$} \\
\hline Mtnds & $\begin{array}{l}\text { How easy is it for the household to } \\
\text { meet its water needs? }\end{array}$ & \\
\hline Mtndsreason & $\begin{array}{l}\text { Why did respondent give the answer } \\
\text { for ease of meeting water needs? }\end{array}$ & \\
\hline Occupation & $\begin{array}{l}\text { What is the occupation of the head of } \\
\text { household? }\end{array}$ & \\
\hline Occupbin & $\begin{array}{l}\text { What is the occupation of the head of } \\
\text { household? }\end{array}$ & $\begin{array}{l}0=\text { Farming; } 1=\text { Farming } \& \text { Non-Farm; } \\
2=\text { Non-Farm Income Only }\end{array}$ \\
\hline Ownership & $\begin{array}{l}\text { Does respondent rent or own the } \\
\text { homestead? }\end{array}$ & $0=$ Rent; $1=$ Own \\
\hline Preknow & $\begin{array}{l}\text { Has the respondent ever heard of the } \\
\text { project before? }\end{array}$ & $0=$ Yes; $1=$ No \\
\hline Preknowwhen & $\begin{array}{l}\text { When did the respondent hear about } \\
\text { the project? }\end{array}$ & $\begin{array}{l}0=\leq 1 \text { week; } 1=>\text { week } \leq 1 \text { month; } \\
2=>1 \text { month } \leq 6 \text { months; } 3=>6 \text { months }\end{array}$ \\
\hline Preknowwhere & $\begin{array}{l}\text { Where did the respondent hear about } \\
\text { the project? }\end{array}$ & $0=$ Kigisu; $1=$ Rubona; $2=$ Other \\
\hline Primsource & $\begin{array}{l}\text { What is the household's primary water } \\
\text { source? }\end{array}$ & $\begin{array}{l}0=\text { Pond } ; 1=\text { Spring; } 2=\text { Dam; } \\
3=\text { Borehole }\end{array}$ \\
\hline Purchase & Does household purchase water? & $0=$ Yes; $1=$ No \\
\hline Purchcost & What is the price per jerrycan? (UGX) & Scalar \\
\hline Purchqty & $\begin{array}{l}\text { How Many jerrycans does the } \\
\text { household purchase daily? }\end{array}$ & Scalar \\
\hline Quality & $\begin{array}{l}\text { How good is the water from your } \\
\text { primary source for drinking? }\end{array}$ & $0=$ Very Bad; $1=$ Fair; $2=$ Very Good \\
\hline Reasonpubmore & $\begin{array}{l}\text { Why would respondent pay more per } \\
\text { unit from a public tap than a private } \\
\text { tap? }\end{array}$ & $\begin{array}{l}1=\text { Water at Private Tap Expected to } \\
\text { be Less than Public; } 2=\text { Family will } \\
\text { Waste Water from Private Tap }\end{array}$ \\
\hline ReasonzeroWTP & $\begin{array}{l}\text { What is the primary reason the } \\
\text { respondent is not willing to pay any } \\
\text { amount for the water? }\end{array}$ & $\begin{array}{l}0=\text { Poor; } 1=\text { Fear Money will be } \\
\text { Mismanaged by Committee; } \\
2=\text { Water Should be Free }\end{array}$ \\
\hline Sex & Respondent's gender & $0=$ Male; $1=$ Female \\
\hline Ttlhhpop & Total number of people in household & Scalar \\
\hline Waterpercap & Water use per person per day (Liters) & Scalar \\
\hline
\end{tabular}




\begin{tabular}{|c|c|c|}
\hline Variable & Question/Information & Response \\
\hline WTPprivate & $\begin{array}{l}\text { Maximum amount household would be } \\
\text { willing to pay per } 20 \mathrm{~L} \text { from a private } \\
\text { tap? (UGX) }\end{array}$ & \\
\hline WTPpublic & $\begin{array}{l}\text { Maximum amount respondent would } \\
\text { be willing to pay per } 20 \mathrm{~L} \text { from a public } \\
\text { tap? (UGX) }\end{array}$ & \\
\hline & & $\begin{array}{l}0=\text { Clean; } 1=\text { Quantity; } 2=\text { =Nearness; } \\
3=\text { Repairs; } 4=\text { Clean \& Near; }\end{array}$ \\
\hline WTPreason & $\begin{array}{l}\text { What is the main reason respondent is } \\
\text { willing to pay the highest amount bid } \\
\text { for public tap? }\end{array}$ & $\begin{array}{l}5=\text { Clean \& Near \& Affordable; } \\
6=\text { Unhappy with Current Water } \\
\text { Situation; } 7=\text { Affordable; } 8=\text { It is } \\
\text { expected; } 9=\text { Household is Poor; } \\
10=\text { Clean \& Repairs }\end{array}$ \\
\hline WTPvillagebin & $\begin{array}{l}\text { Maximum amount respondent would } \\
\text { be willing to pay per } 20 \mathrm{~L} \text { from a public } \\
\text { tap? (UGX) }\end{array}$ & $\begin{array}{l}0=0 ; 1=100 \text { UGX; } 2=200 \text { UGX; } \\
3=400 \text { UGX; } 4=600 \text { UGX; } 5=800 \\
\text { UGX }\end{array}$ \\
\hline Yrsreside & $\begin{array}{l}\text { How many years has respondent lived } \\
\text { at location? }\end{array}$ & Scalar \\
\hline
\end{tabular}




\section{Results and Discussion}

\subsection{Descriptive Statistics}

A total of 122 households were surveyed. Respondents were almost evenly divided by gender with 60 men (49\%) and 62 women (51\%) being interviewed. Demographic information is summarized in Table 4.1.1. Significant results from the health and water use behavior survey data include the following. $72 \%$ of households surveyed indicated that at least one member of the household experienced diarrhea in the previous month, with $84 \%$ of those cases belonging to children with an average incidence of 0.4 incidence of diarrhea/child/month (see Table 4.1.2 for more detail).

$68 \%$ of households indicated that they 'always' boil their drinking water while another $16 \%$ indicated they 'sometimes' boil their drinking water. The researchers' observations in surrounding communities indicated a much lower percentage of rural households boiling drinking water. It is the opinion of the research team that the difference may be due to a compliance bias from the subjects. With $98 \%$ of respondents indicating they believe the water is bad for drinking, before they were asked about boiling drinking water, it is likely the subjects felt pressure to report that they boil their water more frequently than they do.

$98 \%$ of households indicated it is 'very difficult' to meet their daily water needs with more than $50 \%$ indicating that the cleanliness of the water sources was the primary reason for the level of difficulty (Table 4.4). The vast majority of households indicated their primary water source was one of the unprotected open sources in the area while less than $2 \%$ report using the distant borehole as their primary source. 
Table 4.1

Summary Household Demographics

\begin{tabular}{lcccccc}
\hline Variable & $\mathrm{n}$ & Mean & Median & SD & Min & Max \\
\hline Age (years) & 122 & 40.9 & 37.0 & 15.7 & 18 & 80 \\
Number of Children in Household & 122 & 4.04 & 4.0 & 2.84 & 0 & 14 \\
Number of Adults in Household & 122 & 2.10 & 2.0 & .866 & 1 & 5 \\
Total Residents in Household & 122 & 6.14 & 6.0 & 3.26 & 1 & 18 \\
Years of School & 121 & 4.17 & 4.0 & 3.35 & 0 & 13 \\
Number of Years at Residence & 121 & 13.2 & 8.0 & 13.1 & .17 & 76 \\
Distance to Current Water source $(\mathrm{km})$ & 122 & 1.02 & 1.17 & .269 & .255 & 1.57 \\
Distance to Proposed Village Tap $(\mathrm{km})$ & 122 & .455 & .15 & .466 & .010 & 1.75 \\
Annual Income $(* 10,000$ UGX) & 108 & 96.6 & 69.0 & 96.1 & 2 & 370 \\
Log $_{10}$ Income $($ UGX) & 108 & 5.74 & 5.84 & .519 & 4.3 & 6.57 \\
\hline
\end{tabular}

Table 4.2

Frequency of Diarrhea in Previous Month

\begin{tabular}{lccc}
\hline Variable & Mean & Median & SD \\
\hline How Often Children Experienced Diarrhea in Last Month & 2.65 & 2.00 & 2.25 \\
Incidence of Diarrhea per child in last month & .416 & .333 & .438 \\
How Often Adults Experienced Diarrhea in Last Month & 1.43 & 1.00 & .831 \\
\hline
\end{tabular}

$81 \%$ of households indicated using some form of rainwater as a secondary source to meet their water needs. It was also observed that during the wet seasons, informal rainwater harvesting is almost universally practiced in the area. $25 \%$ of households reported purchasing water regularly. The average purchase is 3.6 jerrycans per day at a cost of almost 500 Shillings per jerrycan. 


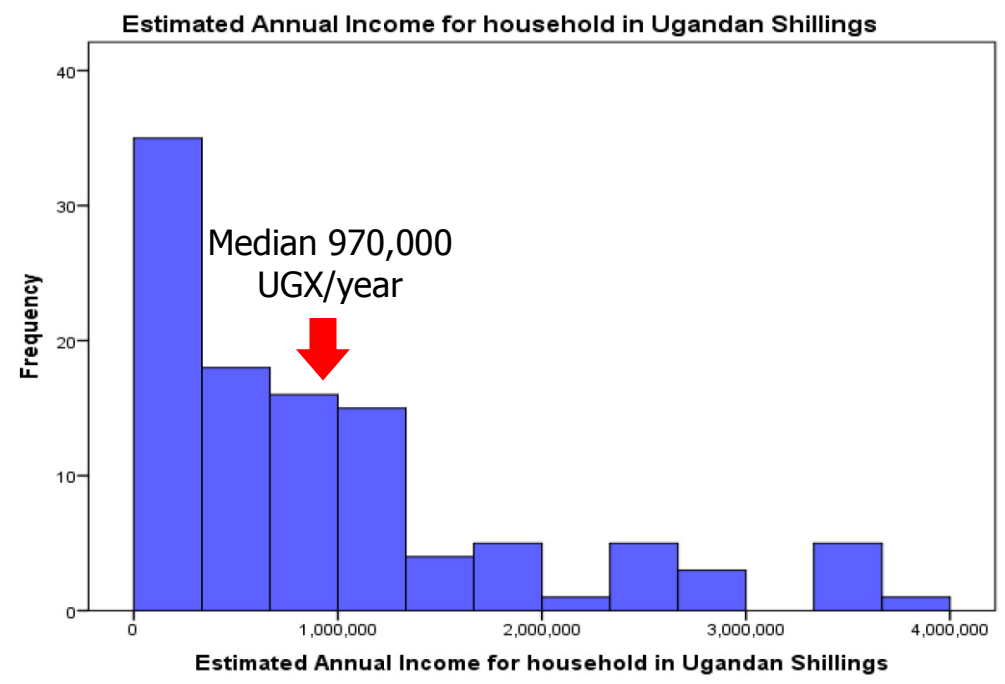

Figure 3: Distribution of Household Estimated Annual Income

MDG 7.3 defines 'reasonable access to an improved water source' as access to a minimum of $20 \mathrm{~L}$ per person per day within $1 \mathrm{~km}$ of the household. The results for households in Kigisu are shown in Figure 3 along with the MDG standards. This study asked respondents how much water they used in their home daily and therefore some water use may not have been captured since people often wash clothes and bath in natural bodies of water. In spite of this unknown error for water use, with more than half of households report using 10 liters per Capita per Day $(\mathrm{l} / \mathrm{c} / \mathrm{d})$ or less, water use in Kigisu is clearly a problem for the health and prosperity of the community.

Residents express a strong desire to have clean water, with some households paying up to 500 shillings for each $20 \mathrm{~L}$ jerrycan of water fetched from the deep well site. Most residents do not have sufficient income to allow for water purchases. 


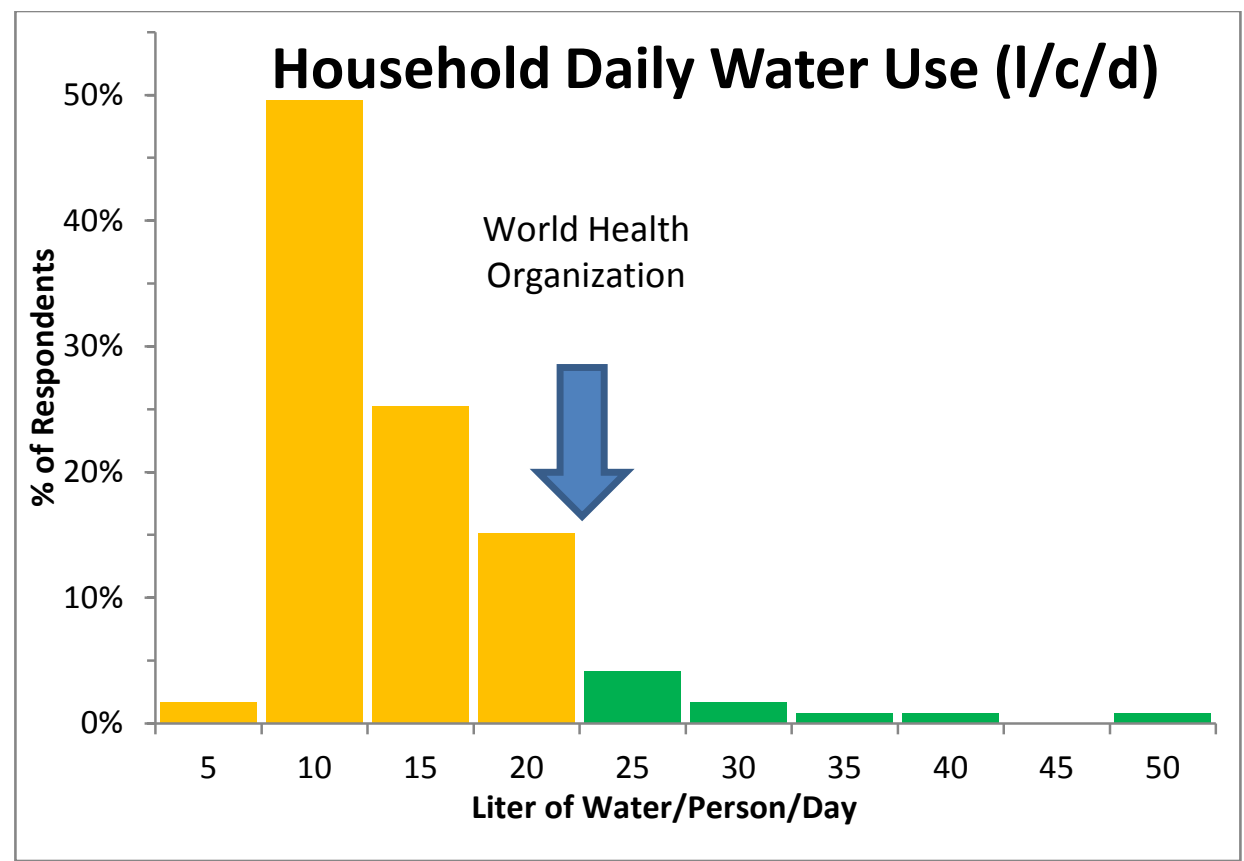

Figure 4: Distribution of Daily Water Use Per Capita

The mean willingness to pay at a public tap is 286 shillings per 20 liters. Table 4.3 summarizes the WTP responses. WTP statistics can be helpful on their own, but understanding what influences WTP is ultimately a more interesting, and helpful, question. Other studies have found gender to be a determinant of WTP, primarily that women have a higher WTP than men; this is not true of these communities. Men had a mean WTP of 292 shillings (SD 242) and women 281 shillings (SD 219) per jerrycan from a village tap. Performing a 2-tailed F-test showed no statistical significance between women and men's WTP in Kigisu.

Respondents who currently purchase water did not have a statistically significant difference in WTP for either a private or public tap than those who do not currently purchase water.

Some WTP studies also show a correlation between education and WTP; this study did not show a statistically significant difference in WTP for those respondents with $<2$ years of school $(n=36)$ versus those with $>6$ years $(n=37)$. 
Willingness to Pay for Improved Water Sources

\begin{tabular}{lrrrr}
\hline Variable & N & Mean & Median & Std. Deviation \\
\hline WTP per 20L Private Tap (UGX) & 54 & 202 & 200 & 149 \\
WTP per 20L Village Tap (UGX) & 122 & 286 & 200 & 229 \\
\hline
\end{tabular}

The data showed no correlation between income and WTP. Without an alternative measure, such as household wealth, to evaluate; the reason for the lack of correlation cannot be tested but may be explained by the difficulties of estimating the incomes of subsistence farmers or the mean level of income in the area may be below a threshold for price sensitivity.

Evaluating WTP results from each team of enumerators using one-way ANOVA showed that the mean WTP values were not consistent. By removing one team at a time and retesting it was determined that one team (Team $D$ ), of the six used, did have a statistically significant difference in their recorded mean WTP (Appendix 8.3 ). This team conducted $18 \%$ of the total 122 interviews. While their sample did not have significant differences in household size, income or distance from existing sources, they were deployed to a specific satellite 'community' that may have different characteristics that were not captured in the survey. Eliminating these responses gives a mean WTP for 20L at a public tap of 261 shillings. Because the mean WTP value still falls within the range of 200-300 shillings, the responses were left in the analysis.

It is important to note that respondents are implicitly providing WTP for water that will be used for drinking and cooking. It can be assumed that most households will continue to use the free sources for needs other than drinking and cooking.

Of the 10 instances a respondent indicated they would pay more for water from the public tap, 9 were because they felt household tap water should be less 
expensive. This is true of neighboring communities where water from the private tap costs roughly 4000 Shillings per $1 \mathrm{~m}^{3}$, or 80 Shillings per jerrycan compared to 200 at the public taps. The other respondent indicated his reason was based on a belief that having a private tap would encourage his family to use more water and possibly begin wasting it, resulting in even greater cost over time. Studies have shown it to be true that water use will substantially increase when households are connected to piped water (Goldblatt 1999).

When asked to give the primary reason they were willing to pay the final bid price for water almost $70 \%$ indicated they were willing to pay because the proposed system would provide 'clean' water. Only $4 \%$ of the respondents stated their primary reason for WTP was for repairs of the system. Of those respondents who indicated they were unwilling to pay any amount for water, lack of money was the almost unanimous reason given although some indicated doubt that the system would ever be built.

At the end of the interview respondents were asked if they had any additional questions or comments for the project administrators. These comments are tabulated in Appendix 8.3, but it is worth noting that more than $88 \%$ of the comments expressed gratitude and support for a community water project.

\subsection{Modeling}

More than 75 variable combinations were modeled and more than seven produced robust results. Summary results of the goodness of fit tests for seven models are listed in Table 4.4. It is clear that the model produces strong predictive results and is a significant improvement over the base model.

The inclusion of several variables proved to consistently improve the models predictive capability. The variables (see Table 3.1 for variable definitions and explanations): Children, distexistbin, mtndreason, crops, occbin, and illperchild 
were present in the models with the best 'goodness of fit' statistics. The inclusion of edubin, boil and sex showed a moderate improvement in the fit of some models. The variables: age, income, logincome, ownership, and education generally did not improve the model's predictive power.

Model $B$ shows that the removal of the variable for binned occupations, occbin, dramatically reduces the pseudo $\mathrm{R}^{2}$ statistics. Because $83 \%$ of respondents indicated that farming was a primary occupation, the variable occbin will have little power due to the lack of variability. There may also be concerns over multicolinearity issues with the corresponding variable crops. 
Table 4.4

Goodness of Fit Test Results for Selected Probit Models

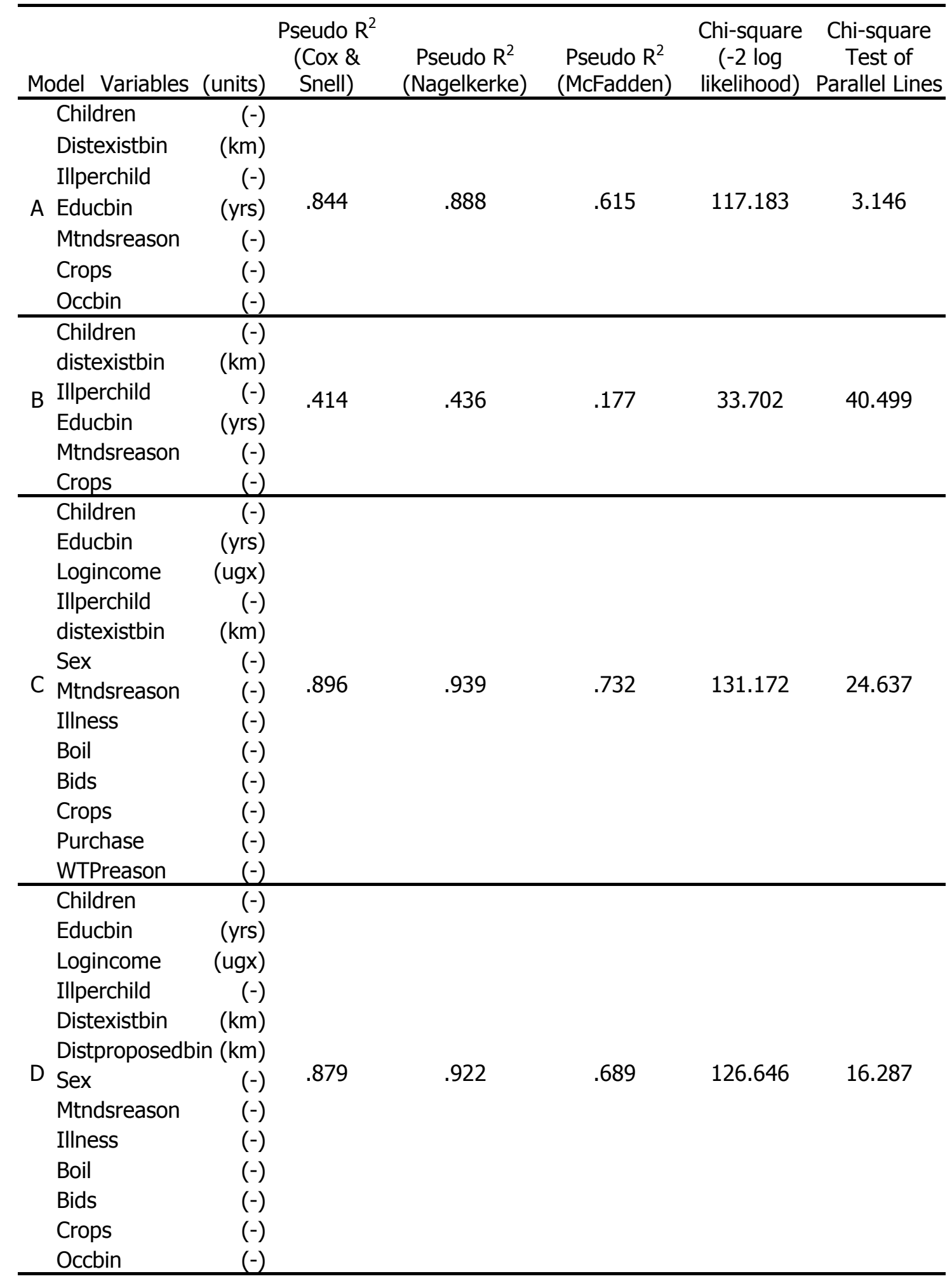


Table 4.4 (Continued)

Goodness of Fit Test Results for Selected Probit Models

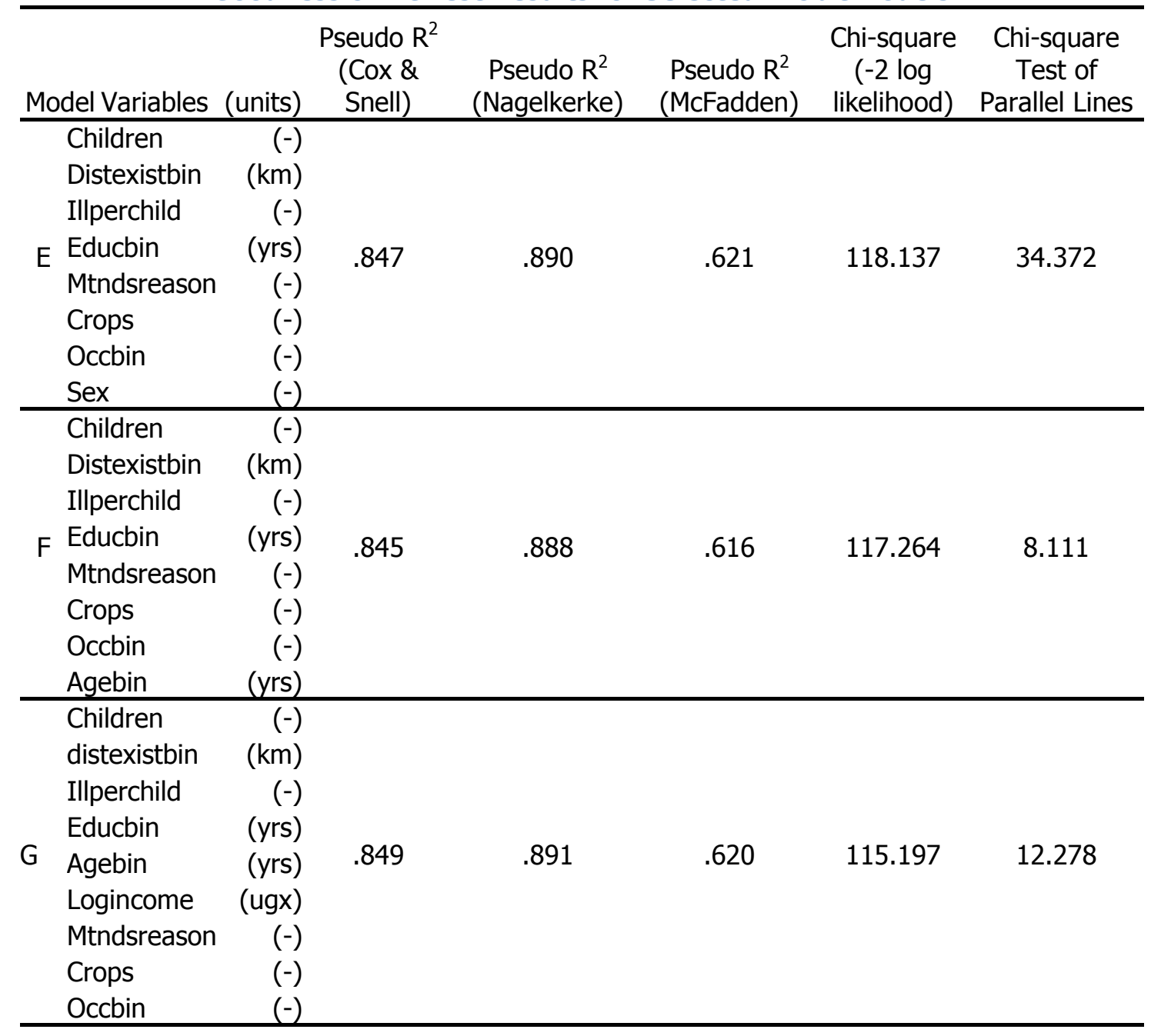

Model $\mathrm{A}$ is highlighted in Table 4.5 for its parsimony and goodness of fit. The dependent variable 'WTP per jerrycan from a public tap' is related to several independent variables. When evaluating covariates in the model a positive coefficient indicates a positive relationship between predictors and outcome. The sign of a factor's coefficient can be evaluated the same as a covariate while additionally noting that the magnitude of the coefficient for a factor is also predictive. A larger coefficient indicates a greater probability that the outcome will be in one of the higher WTP categories. 
The number of children in the household has a significantly correlated negative effect on WTP. This could be attributed to more children reducing the household's income per capita. The negative relationship may also reflect the value of 'free' labor from children who are often expected to fetch water for the household.

Households distance to their existing primary source has a strong positive correlation with WTP. Although the coefficient is relatively small in magnitude compared to other independent variables it does show that those households currently transporting water the furthest have a higher WTP than households closer to their primary source.

The respondents' reason for the ranking of how easy it is to meet their water needs adds robustness to the model. The specific reasons: distance to source, water is unclean, and scarcity, have a significant, positive correlation to WTP. This variable proved to be one of the strongest predictors in multiple iterations of the model.

The variable crops, which classifies the various crops the farmer grows, improves the model although most individual responses do not show a significant correlation to WTP. This may be due to the variable serving as a proxy for some income or wealth factor since it shows that coffee, plantain and g-nuts (cash crops) are the responses with the strongest correlation. The variable was binned using a variety of strategies but no definitive relationship was obtained. 
Table 4.5

Ordered Probit Estimated WTP Model A with Variables

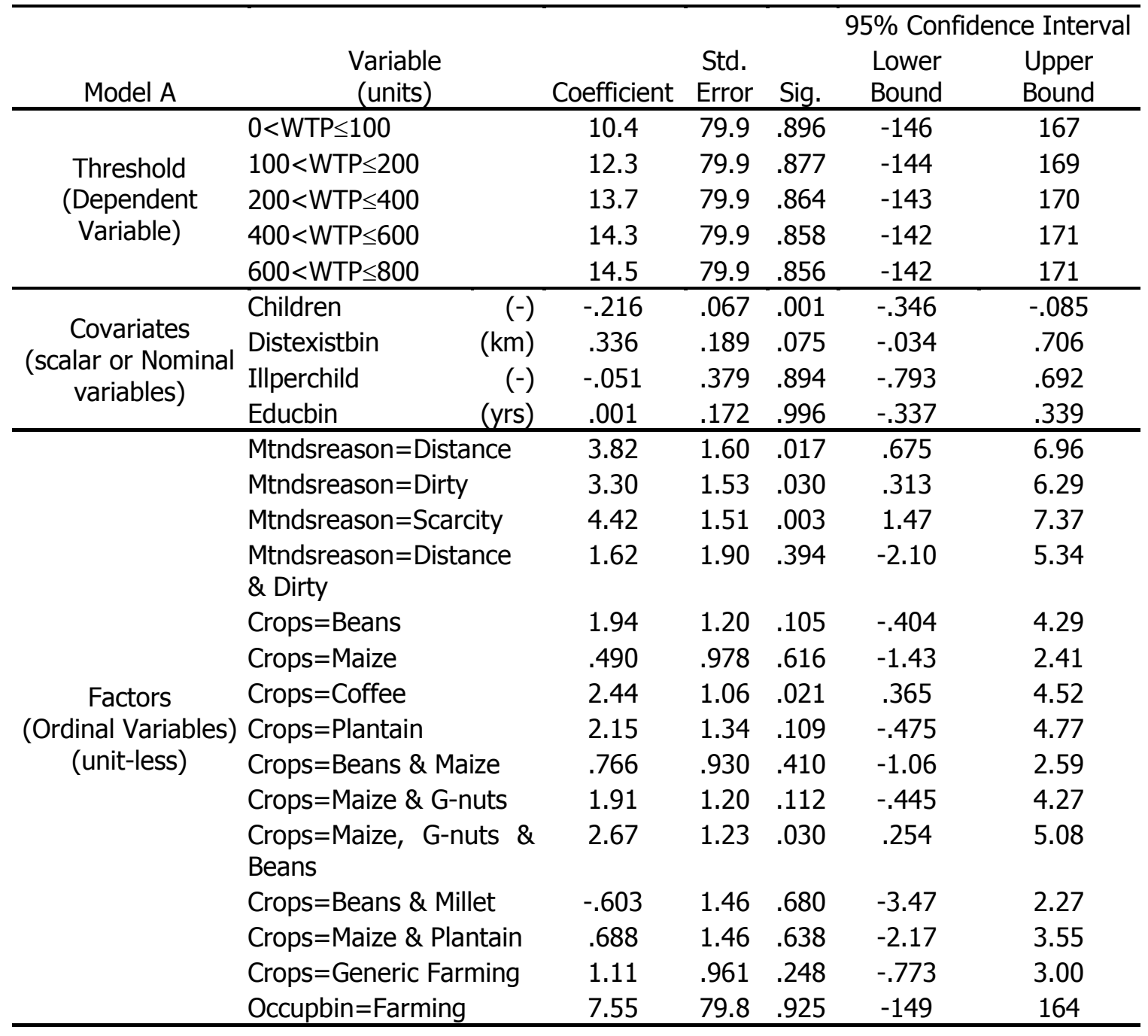




\section{Conclusions and Recommendations}

Research was conducted in the villages of Kigisu and Rubona, Uganda, to collect information about demographics, health, current water situation and WTP for an improved water source. The CVM and an iterative bidding process were used to estimate households WTP for O\&M costs of an improved water source. A total of 122 interviews were conducted over two days in August, 2011. The mean WTP was 286 Ugandan shillings per 20L of water from a public tap and 202 shillings from a private tap. WTP was significantly correlated to the number of children in the home, and the households distance from their existing source.

The data were analyzed using an ordered probit model to test the relationship between independent variables and WTP. The ordered probit model demonstrated strong goodness of fit and validated the reliability of the data. The model showed that WTP was inversely related to the number of children in the home and positively related to the distance to the existing water source. Some variables other studies have found to be correlated such as education, income, gender and home ownership were not significantly correlated to WTP in this study.

Ultimately the goal of this research is to help the people of Kigisu and Rubona to improve their standard of living through improved access to safe drinking water. Based on the mean WTP of 286 Shillings per 20 liters from a public tap that this study revealed, the proposed water source project in Kigisu has a high likelihood of long-term success if the O\&M costs can be kept at a reasonable level. Based on the knowledge that the nearby communities of Kasambya and Mukaaga report full cost recovery for their water system, priced at 200 shillings per 20 
liters, a well-managed water system in Kigisu can expect similar results with a similar pricing structure.

It is recommended that KIDECAFO pursue an improved water source for the communities of Kigisu and Rubona. The research clearly indicates that the mean WTP is sufficient to support an improved water system.

This study demonstrates that it is possible to implement a small-scale WTP survey in a rural village in a developing country and produce reliable and useful results. 


\section{Comments}

This research was only made possible through the partnership between the author and KIDECAFO. Without a strong link between the researcher and the community the challenges of conducting an academic study in the developing world could have easily thwarted the research. Anyone considering this type of study in the developing world is advised to create a partnership with a strong local organization from the very beginning of the research.

The energy inputs needed to run a water pump in the proposed system would be the largest portion of the O\&M expenses and care should be taken to minimize this expense and provide flexibility in the case of fuel shortages and price spikes. The design of the proposed system must take more factors into account than simply WTP. The new system must be designed to be rugged, easily repairable with local knowledge, constructed with locally available parts and materials, and preferably with a multi-fuel or alternative energy input.

It is further recommended that KIDECAFO and the community leaders consider alternatives to the proposed large-scale improved water system. Based on the mean WTP of 286 Shillings that this study revealed, along with the clear indication that cleanliness is valued much more than accessibility/location, it may be possible for the community to make satisfactory improvements to its existing water supply without the need for outside funding in the near term.

It may also be possible to satisfy the communities' needs, and desires, for improved water by constructing a simple borehole with hand pump(s) at one, or more, locations near the existing sources. This option would provide the highly valued clean water and may be done more economically than the currently proposed system that would require a pump, large storage tank and piping to 
tap stands. The communities' interest in optional solutions must be determined through additional questioning before any plan is implemented.

Since the survey indicates a very clear preference for clean water in the community ( $80 \%$ of respondents) the planners should consider technical solutions that involve simply improving the water sources that are currently available rather than creating an entirely new system. It may be more cost effective and timely to improve the current open sources through expansion of the reservoirs and the addition of some treatment option, possibly a large sand filter at one, or more, source.

Although this study did not ask about a preferred method of payment a small number of respondents indicated a preference for paying monthly for the water. This is something the water committee should further research with the community.

Enumerators and survey administrators are a researcher's link to quality data. The challenges of properly training enumerators are significant but must be understood and overcome. Enumerators without a proper understanding of the survey instrument and proper interviewing techniques will undoubtedly provide data that is not ideal, or simply unusable. Investing in several days of training, designed and conducted with the local partner organization, provided data that were, on the whole, reliable, consistent and usable.

This study has a very small sample size ( $n=122$ households) over a small area $\left(\sim 9 \mathrm{~km}^{2}\right)$ of rural Uganda. The scope of the study was appropriate for its intended purpose but care should be taken in attempting to extrapolate, or compare, the results and conclusions presented. 


\section{References}

Abdul S, Eatzaz A. 2007. Willingness to Pay for the Quality of Drinking Water. The Pakistan Development REview 46(4 part II):767-777.

Arrow K, United States. National O, Atmospheric A. 1993. Report of the NOAA panel on contingent valuation. S.I.: S.n.].

Boadu FO. 1992. CONTINGENT VALUATION FOR HOUSEHOLD WATER IN RURAL GHANA. Journal of Agricultural Economics 43(3):458-465.

Boardman AE. 2006. Cost-benefit analysis :concepts and practice. Upper Saddle River, N.J.: Pearson/Prentice Hall,c2006.

Briscoe J, de Castro PF, Griffin C, North J, Olsen O. 1990. Toward Equitable and Sustainable Rural Water Supplies: A Contingent Valuation Study in Brazil. The World Bank Economic Review 4(2):115-134.

Carson RT. 2000. Contingent Valuation: A User's Guidet. Environmental Science \& Technology 34(8):1413-1418.

Carson RT, Flores NE, Meade NF. 2001. Contingent Valuation: Controversies and Evidence. Environmental and Resource Economics 19(2):173-210.

Diamond PA, Hausman JA. 1994. Contingent Valuation: Is Some Number better than No Number? The Journal of Economic Perspectives 8(4):45-64.

Economist T. 2010. Country Report Uganda February 2010. London: Economist Intelligence Unit. Report.

Goldblatt M. 1999. Assessing the effective demand for improved water supplies in informal settlements: a willingness to pay survey in Vlakfontein and Finetown, Johannesburg. Geoforum 30(1):27-41.

C.I.A. World Factbook [Internet]. 2012. U.S. Government. [updated 4-April, cited 4-April]. Available from: https://www.cia.gov/library/publications/theworld-factbook/geos/ug.html

Gunatilake HM, Asian Development B, Asian Development Bank E, Research D. 2007. Good practices for estimating reliable willingness-to-pay values in the water supply and sanitation sector. Metro Manila, Philippines: Asian Development Bank.

McPhail A. 1993a. Overlooked Market for Water Connections in Rabat's Shantytowns. Journal of Water Resources Planning and Management 119(3):388-404.

McPhail AA. 1993b. The "five percent rule" for improved water service: Can households afford more? World Development 21(6):963-973.

Mu X, Whittington D, Briscoe J. 1990. Modeling village water demand behavior: A discrete choice approach. Water Resour. Res. 26(4):521-529.

Nauges C, Whittington D. 2010. Estimation of Water Demand in Developing Countries: An Overview. The World Bank Research Observer 25(2):263294. 
Perez-Pineda F. 1999. Estimating the willingness to pay for water services in developing countries : a case study of the use of a contingent valuation survey in El Salvador, Central America.

Singh B, Ramasubban R, Bhatia R, Briscoe J, Griffin CC, Kim C. 1993. Rural water supply in Kerala, India: How to emerge from a low-level equilibrium trap. Water Resour. Res. 29(7):1931-1942.

MDG Monitor [Internet]. 2010. United Nations Development Programme. [updated 26-March, cited 26-March]. Available from: http://www.mdgmonitor.org/goal7.cfm

Van Damme HMGW, A. 1984. Technology Choices for the Decade. Water and Sanitation: Economic and Sociological Perspectives.

Wedgewood A, Sansom K. 2003. Willingness-to-pay survey - a streamlined approach - : guidance notes for small town water services. Loughborourgh: WEDC (Water, Engineering and Development Centre).

Whittington D, Briscoe J, Mu X, Barron W. 1990. Estimating the Willingness to Pay for Water Services in Developing Countries: A Case Study of the Use of Contingent Valuation Surveys in Southern Haiti. Economic Development and Cultural Change 38(2):293-311.

Whittington D, Lauria DT, Mu X. 1991. A study of water vending and willingness to pay for water in Onitsha, Nigeria. World Development 19(2-3):179198.

Whittington D. 1998. Administering contingent valuation surveys in developing countries. World Development 26(1):21-30.

Whittington D. 2002. Improving the Performance of Contingent Valuation Studies in Developing Countries. Environmental and Resource Economics 22(1):323-367.

Global Health Observatory Data Repository [Internet]. 2008. Geneva. [updated 18-March-2012, cited 18-March]. Available from: http://apps. who.int/ghodata/?vid=20300\&theme=country

Currency Converter [Internet]. 2011. Yahoo.com. [updated 2012, cited August12-2011]. Available from: http://finance.yahoo.com/currencyconverter/; ylt=An6i6puou5tSMymNc46ortOzOKB4; ylu=X3oDMTE4dDg0Z jNhBHBvcwMyBHNIYwNjdXJyZW5jaWVzTmF2BHNsawNjdXJyZW5jeWNvbn Y-\#from=USD;to=UGX;amt=1 


\section{Appendices}

\subsection{Survey}

8.2 Data

\subsection{Analysis}

